e-ISSN; 2528-0325 ISSN; 2528-0317 Tasharruf : $\mid$ Vol. 2 No. 1 Juni 2017 Journal Economic and Business Of Islam

\title{
Pemahaman Masyarakat Tentang Jual Beli Cengkeh Yang Masih Di Pohon (Ijon) Di Kecamatan Passi Barat Kabupaten Bolaang Mongondow
} Syamsuddin A. K Antuli dien.antuli@gmail.com Institut Agama Islam Negeri (IAIN) Manado

People Understanding Of Buying And Selling Cloves Which Are Still On Trees (Ijon) In The District Of Passi Barat Bolaang Mongondow

\section{Abstract}

The practice of buying and selling by using Ijon are widely practised in the villages such as pasi Barat when the cloves are still on trees.

Based on this description, the writer tries to investigate on people understanding of buying and selling cloves which are still on trees (Ijon). This is field research with descriptive analyses methods that is qualitative research that will produce normative data acquired through direct interview on purposive sampling. Purposive sampling is selected due to the ability to represent the population. Furthermore, documentation technique is used to explore existing data related to research based on data collected and the analysis performed it can be concluded that people understanding especially cloves farmers on Ijon styles buying and selling is varied. According to researcher observation, the varied understanding are based on this issue is due to the low knowledge on religion. Most respondents cannot respond when asked about the Ijon.

Keywords: Buying and Selling, Understanding and Ijon

\section{ABSTRAK}

Praktek jual beli dengan sistem Ijon banyak ditemukan di daerah pedesaan, salah satunya di Kecamatan Passi Barat yakni jual beli buah cengkeh yang masih di Pohon.

Berdasarkan deskripsi tersebut maka penyusun mencoba untuk meneliti bagaimana Pemahaman Masyarakat terhadap pelaksanaan praktek jual beli cengkeh yang masih di pohon. Jenis penelitian ini adalah penelitian lapangan (field research) yang bersifat deskriptif-analitis, yaitu penelitian kualitatif yang menghasilkan data normatif yang diperoleh dari wawancara langsung dengan menggunakan teknik sampling, yakni purposive sampling, yaitu sampel dipilih berdasarkan pertimbangan peneliti yang dianggap bisa mewakili populasi. Di 
e-ISSN; 2528-0325 ISSN; 2528-0317 Tasharruf : Vol. 2 No. 1 Juni 2017 Journal Economic and Business Of Islam

samping itu digunakan teknik dokumentasi untuk menggali data-data yang ada dan data-data lain yang berkaitan dengan penelitian. Berdasarkan data-data yang diperoleh dan analisis yang dilakukan, maka dapat di simpulkan bahwa Pemahaman masyarakat khususnya para petani cengkeh tentang jual beli Ijon ini sangat beragam, bahkan ada yang sama sekali tidak memahaminya. Keberagaman tersebut sesuai hasil observasi dan pengamatan peneliti karena dipengaruhi oleh Minimya Pengetahuan Agama. Informasi tentang persoalan Ijon sesuai dengan hasil observasi tanya jawab peneliti rata-rata tidak mengetahui bahkan tidak bisa menjawab.

Kata Kunci: Jual-beli, pemahaman dan Ijon

\section{Latar Belakang}

Dalam hal ini, Ahmad Azhar Basyir mengemukakan bahwa manusia itu dikenal sebagai mahluk sosial, yaitu mahluk yang ditaqdirkan hidup bermasyarakat. Sebagai mahluk sosial, tentunya manusia selalu berinteraksi antara satu individu dengan individu yang lain. Untuk memenuhi kebutuhan hidup, manusia memerlukan orang lain. Aktifitas interaksi antara seseorang dengan orang lain adalah hubungan yang dalam Islam dikenal dengan Muamalah (Ahmad Azhar Basyir; 2000; 11)

Sesungguhnya Islam telah menghalalkan dan memperbolehkan kepemilikan individu atas harta benda karena ada hikmah yang mendalam. Dengan adanya kepemilikan individu akan memberikan dorongan kepada individu untuk berani melakukan koreksi terhadap suatu tindkan kezhaliman yang dilakukan oleh seorang pemimpin. Lain halnya ketika harta kekayaan yang dimiliki oleh setiap individu ditentukan oleh sebuah otoritas tertentu, masinbg-masing hanya akan berperan sebagai pekerja, dan sangat mustahil bagi mereka untuk berani mempunyai pandangan yang berbeda dengan otoritas tersebut, karena seluruh kehidupan mereka bergantung kepada kekuasaan mereka dan pemerintah yang mempunyai otoritas penuh untuk menentukan arah dan perjalan hidup setiap individu (Abdul Sami' al-Misri, 2006; 29). 
e-ISSN; 2528-0325 ISSN; 2528-0317 Tasharruf : Vol. 2 No. 1 Juni 2017 Journal Economic and Business Of Islam

Salah satu wujud interaksi adalah disyari'atkannya akad jual beli. Salah satu bentuk jual beli yang saat ini masih terjadi ditengah-tengah masyarakat adalah jual beli buah cengkeh yang masih di pohon yang dalam pembahasan Fiqh Muamalah, jual beli tersebut dikategorikan sebagai jual beli Gharar.

Jual beli gharar adalah jual beli barang yang mengandung kesamaran. Hal itu dilarang dalam Islam, sebab Rasulullah SAW. bersabda melalui haditsnya yang diriwayatkan oleh Imam Ahmad yang Artinya : “ Janganlah Kamu membeli Ikan didalam air karena jual beli seperti itu termasuk gharar (menipu), Rahmat Syafe'I, 2006; 97.

Ulama fiqh sepakat bahwa membeli buah-buahan yang belum ada di pohonnya tidak sah. Namun ulama juga berbeda pendapat apabila pembeli disyaratkan untuk memanen buah-buahan itu, maka jual beli itu sah. Jumhur ulama berpendapat bahwa menjual buah-buahan yang belum layak panen, hukumnya bathil, M. Ali Hasan, $2003 ; 138$

Dalam masyarakat di kecamatan Passi Barat, khusunya petani Cengkeh terdapat suatu kekeliruan bahwa buah cengkeh yang baru berkembang bahkan ada yang belum berbuah sudah diperjualbelikan. Hal ini merupakan ketertarikan peneliti untuk melakukan penelitian tentang pemahaman masyarakat yang berhubungan dengan jual beli.

Dari penjelasan pada latar belakang sebagaimana tersebut di atas, tentunya transakasi jual beli sangat luas cakupannya. Karena keterbatasan waktu, maka penelitian ini akan mengambil satu segi dalam transaksi jual beli yang difokuskan pada Pemahaman Masyarakat tentang Jual Beli Cengkeh yang Masih di Pohon (Ijon) di Kecamatan Passi Barat Kabupaten Bolaang Mongondow.

\section{Rumusan Masalah}

Peneliti perlu membuat Rumusan Masalah agar penelitian ini lebih terarah. Adapun Rumusan Masalahnya adalah "Bagaimana Pemahaman Masyarakat Petani Cengkeh terhadap Jual Beli buah Cengkeh yang masih di Pohon di Kecamatan Passi Barat”. 
e-ISSN; 2528-0325 ISSN; 2528-0317 Tasharruf : Vol. 2 No. 1 Juni 2017 Journal Economic and Business Of Islam

\section{Tujuan Penelitian}

Tujuan penelitian adalah peneliti ingin mengetahui bagaimana pemahaman masyarakat khususnya bagi pelaku yang terkait dengan jual beli buah cengkeh yang masih di pohon bila dipandang dari aspek agama atau pendekatan hukum Islam.

\section{LANDASAN TEORI}

\section{Teori Pemahaman}

Pemahaman Pemahaman ini berasal dari kata"Faham" yang memiliki arti tanggap, mengerti benar, pandangan, ajaran, Plus A.Partanto M. Dahlan AL-Bary, 1994; 279. Disini ada pengertian tentang pemahaman yaitu: kemampuan memahami arti suatu bahan pelajaran, seperti menafsirkan, menjelaskan atau meringkas atau merangkum suatu pengertian. kemampuan semacam ini lebih tinggi dari pada pengetahuan, Muhammad Ali,1996; 42.

Pengertian pemahaman dalam kamus ilmiah popular, berasal dari kata faham yang mendapat imbuhan pe-dan-an. Faham menurut bahasa artinya tanggap, mengerti benar, pandangan, ajaran. Pemahaman didefinisikan proses berpikir dan belajar, (Paul A Partanto dan M. Dahlan Al Barry, 2001; 172). Dikatakan demikian karena untuk menuju ke arah pemahaman perlu diikuti dengan belajar dan berpikir. Pemahaman merupakan proses, perbuatan dan cara memahami, (W.J.S. Porwadarminto, 1991; 636). Sedangkan dalam taksonomi bloom, "kesanggupan memahami setingkat lebih tinggi dari pada pengetahuan. Namun, tidaklah berarti bahwa pengetahuan tidak dipertanyakan sebab untuk memahami, perlu terlebih dahulu mengetahui atau mengenal, (Nana Sudjana, 2008; 24).

Pemahaman adalah tingkatan kemampuan yang mengharapkan seseorang mampu memahami arti atau konsep, situasi serta fakta yang diketahuinya. Dia tidak sekedar hafal secara verbalitas, tetapi memahami konsep dari masalah atau fakta yang ditanyakan, maka operasionalnya dapat membedakan, mengubah, mempersiapkan, menyajikan, mengatur, menginterpretasikan, menjelaskan, mendemonstrasikan, 
e-ISSN; 2528-0325 ISSN; 2528-0317 Tasharruf : Vol. 2 No. 1 Juni 2017 Journal Economic and Business Of Islam

memberi contoh, memperkirakan, menentukan dan mengambil keputusan, (Ngalim Purwanto, 1997; 44).

Pemahaman menurut (Anas Sudijono, 1996; 50) adalah "kemampuan seseorang untuk mengerti atau memahami sesuatu setelah sesuatu itu diketahui dan diingat". Dengan kata lain, memahami adalah mengetahui tentang sesuatu dan dapat melihatnya dari berbagai segi. Pemahaman merupakan jenjang kemampuan berpikir yang setingkat lebih tinggi dari ingatan dan hafalan".

Menurut (Yusuf Anas, 2009; 151) yang dimaksud dengan pemahaman adalah kemampuan untuk menggunakan pengetahuan yang sudah diingat lebih kurang sama dengan yang sudah diajarkan dan sesuai dengan maksud penggunaannya.

Indikator tersebut menunjukkan bahwa pemahaman mengandung makna lebih luas atau lebih dalam dari pengetahuan. Dengan pengetahuan seseorang belum tentu memahami sesuatu dari yang dipelajari. Sedangkan dengan pemahaman seseorang tidak hanya sekedar menghafal sesuatu yang dipelajari, tetapi juga mempunyai kemampuan untuk menangkap makna dari yang dipelajari secara lebih mendalam, dan mampu memahami konsep dari pelajaran tersebut.

\section{Teori Masyarakat}

Tinjauan tentang Masyarakat dalam istilah bahasa Inggris adalah society yang berasal dari kata Latin socius yang berarti (kawan). Istilah masyarakat berasal dari kata Bahasa Arab syaraka yang berarti (ikut serta dan berpartisipasi). Masyarakat adalah sekumpulan manusia yang saling bergaul, dalam istilah ilmiah adalah saling berinteraksi. Suatu kesatuan manusia dapat mempunyai prasarana melalui wargawarganya dapat saling berinteraksi. Definisi lain, masyarakat adalah kesatuan hidup manusia yang berinteraksi menurut suatu sistem adat istiadat tertentu yang bersifat kontinyu, dan yang terikat oleh suatu rasa identitas bersama. Kontinuitas merupakan kesatuan masyarakat yang memiliki keempat ciri yaitu: 1) Interaksi antar wargawarganya, 2) Adat istiadat, 3) Kontinuitas waktu dan 4) Rasa identitas kuat yang mengikat semua warga, (Koentjaraningrat, 1997; 23). 
e-ISSN; 2528-0325 ISSN; 2528-0317 Tasharruf : Vol. 2 No. 1 Juni 2017 Journal Economic and Business Of Islam

Djuretnaa Imam Muhni, (1994: 29-31) keseluruhan ilmu pengetahuan tentang masyarakat harus didasari pada prinsip-prinsip fundamental yaitu realitas sosial dan kenyataan sosial. Kenyataan sosial diartikan sebagai gejala kekuatan sosial didalam bermasyarakat. Masyarakat sebagai wadah yang paling sempurna bagi kehidupan bersama antar manusia.

Menurut Ralph Linton masyarakat merupakan setiap kelompok manusia yang telah hidup dan bekerja bersama cukup lama, sehingga mereka dapat mengatur diri mereka dan menganggap diri mereka sebagai suatu kesatuan sosial dengan batas-batas yang dirumuskan dengan jelas.

Sedangkan masyarakat menurut Selo Soemardjan, (2006; 22) adalah orang-orang yang hidup bersama yang menghasilkan kebudayaan dan mereka mempunyai kesamaan wilayah, identitas, mempunyai kebiasaan, tradisi, sikap, dan perasaan persatuan yang diikat oleh kesamaan.

Menurut Emile Durkheim, (1984 11) bahwa masyarakat merupakan suatu kenyataan yang obyektif secara mandiri, bebas dari individu-individu yang merupakan anggotaanggotanya. Masyarakat sebagai sekumpulan manusia didalamnya ada beberapa unsur yang mencakup : 1) Masyarakat merupakan manusia yang hidup bersama, 2) Bercampur untuk waktu yang cukup lama, 3) Mereka sadar bahwa mereka merupakan suatu kesatuan dan 4) Mereka merupakan suatu sistem hidup bersama.

\section{Teori Jual Beli}

Teori jual beli dalam Islam mengajarkan setiap pemeluknya agar orang yang terjun ke dunia usaha, berkewajiban mengetahui hal-hal yang dapat mengakibatkan jual beli itu sah atau tidak. Ini dimaksudkan agar bermuamalat berjalan dengan sah dan segala sikap dan tindakannya jauh dari kerusakan yang tidak dibenarkan As-Sayyid-Sabiq, 1998; 12.

Jual beli adalah suatu muamalat dan merupakan salah satu kebutuhan manusia sebagai mahluk sosial, karena kebutuhan manusia tidak mungkin dipenuhi 
e-ISSN; 2528-0325 ISSN; 2528-0317 Tasharruf: $\mid$ Vol. 2 No. 1 Juni 2017 Journal Economic and Business Of Islam

sendiri tanpa bantuan dari orang lain, sehingga dalam pelaksanaannya harus selalu mengingat prinsip-prinsip muamalat, yang dapat dirumuskan sebagai berikut : a) Pada dasarnya segala bentuk muamalat adalah mubah, kecuali yang ditentukan lain oleh Al-Qur'an dan al-Hadis, b) Muamalat dilakukan atas dasar sukarela tanpa mengandung unsur paksaan, c) Muamalat dilakukan atas dasar pertimbangan mendatangkan manfaat dan menghindarkan mudarat dalam hidup masyarakat dan, d) Muamalat dilakukan dengan memelihara nilai-nilai keadilan, menghindari unsur-unsur penganiayaan dan unsur-unsur pengambilan kesempatan dalam kesempitan, (Ahmad Azhar Basyir, 2000; 15)

Ijon atau dalam bahasa Arab dinamakan mukhadlaroh, yaitu memperjual belikan buah-buahan atau biji-bijian yang masih hijau, Atau dalam buku lain dinamakan alMuhaqalah yaitu menjual hasil pertanian sebelum tampak atau menjualnya ketika masih kecil (Hamzah Ya'qub, 1992; 124).

Dari pengertian di atas tampak adanya pembedaan antara menjual buah atau bijibijian yang masih di dahan tetapi sudah tampak wujud baiknya dan menjual buah atau biji-bijian yang belum dapat dipastikan kebaikannya karena belum kelihatan secara jelas wujud matang atau kerasnya.

Sebelum madzhab sepakat bahwasanya jual beli buah-buahan atau hasil pertanian yang masih hijau, belum nyata baiknya dan belum dapat dimakan adalah salah satu diantara barang-barang yang terlarang untuk diperjual-belikan. Hal ini merujuk pada Hadits Nabi yang disampaikan oleh Anas ra :

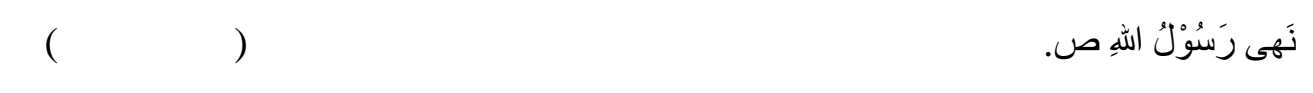

Artinya :

"Rasulullah Saw melarang muhaqalah, mukhadlarah (ijonan), mulamasah, munabazah, dan muzabanah". (HR. Bukhari) 
e-ISSN; 2528-0325 ISSN; 2528-0317 Tasharruf : Vol. 2 No. 1 Juni 2017 Journal Economic and Business Of Islam

Imam Abu Hanifah atau fuqaha Hanafiyah membedakan menjadi tiga alternatif hukum sebagai berikut :

1. Jika akadnya mensyaratkan harus di petik maka sah dan pihak pembeli wajib segera memetiknya sesaat setelah berlangsungnya akad, kecuali ada izin dari pihak penjual.

2. Jika akadnya tidak disertai persyaratan apapun, maka boleh.

Jika akadnya mempersyaratkan buah tersebut tidak dipetik (tetap dipanen) sampai masak-masak, maka akadnya fasad (Ghufron A. Mas'adi, 2002; 139).

Sedangkan para ulama berpendapat bahwa mereka membolehkan menjualnya sebelum bercahaya dengan syarat dipetik. Hal ini didasarkan pada hadits nabi yang melarang menjual buah-buahan sehingga tampak kebaikannya. Para ulama tidak mengartikan larangan tersebut kepada kemutlakannya, yakni larangan menjual beli sebelum bercahaya. Kebanyakan ulama malah berpendapat bahwa makna larangan tersebut adalah menjualnya dengan syarat tetap di pohon hingga bercahaya (Ibnu Rusyd, 1990; 52)

\section{METODE PENELITIAN}

Metode penelitian adalah suatu cara yang digunakan peneliti dalam mengumpulkan data penelitiannya dan dibandingkan dengan standar atau ukuran yang telah ditentukan(Suharsimi Arikunto, 2002; 127). Dalam Penelitian ini guna memperoleh data dan informasi yang objektif dibutuhkan data-data dan informasi yang aktual dan relevan.

Metode yang digunakan peneliti sebagai sarana dan pedoman dalam penelitian ini adalah sebagai berikut:

\section{Pendekatan Penelitian}

Dalam penelitian ini peneliti menggunakan pendekatan kualitatif yaitu untuk mengetahui atau menggambarkan kenyataan dari kejadian yang diteliti sehingga memudahkan peneliti untuk mendapatkan data yang objektif dalam rangka mengetahui dan memahami Pemahaman Masyarakat tentang Jual Beli Gharar yakni 
e-ISSN; 2528-0325 ISSN; 2528-0317 Tasharruf: $\mid$ Vol. 2 No. 1 Juni 2017 Journal Economic and Business Of Islam

Jual Beli buah cengkeh yang masih di pohon pada masyarakat Petani di Kecamatan Passi Barat.

\section{Tipe Penelitian}

Tipe penelitian yang digunakan dalam penelitian ini adalah tipe penelitian deskriptif. Penelitian deskriptif terbatas pada usaha mengungkapkan suatu masalah atau keadaan atau peristiwa sebagaimana adanya sehingga bersifat mengungkapkan fakta dan memberikan gambaran secara obyektif tentang keadaan sebenarnya dari objek yang diteliti.

\section{Unit Analisis}

Unit analisis dalam penelitian ini adalah Pemahaman Masyarakat tentang Jual Beli Gharar yakni Jual Beli buah cengkeh yang masih di pohon pada masyarakat Petani di Kecamatan Passi Barat

\section{Sumber Data}

Menurut Lofland dan Lofland sebagaimana yang dikutip oleh (Lexi J. Moleong, 2001; 62) bahwa sumber data utama dalam penelitian kualitatif ialah kata-kata dan tindakan selebihnya adalah data tambahan seperti dokumen dan lain-lain, Dimana data hasil penelitian didapatkan melalui dua sumber data, yaitu:

\section{Data Primer}

Data primer adalah data yang diperoleh langsung dari hasil wawancara yang diperoleh dari narasumber atau informan yang dianggap berpotensi dalam memberikan informasi yang relevan dan sebenarnya di lapangan.

Dalam penelitian ini, data primer diperoleh dengan menggunakan metode wawancara atau interview yang dilakukan dengan petani, serta masyarakat 
e-ISSN; 2528-0325 ISSN; 2528-0317 Tasharruf : Vol. 2 No. 1 Juni 2017 Journal Economic and Business Of Islam

setempat yang mengetahui dan menjadi pelaku dalam permasalahan jual-beli Cengkeh dengan cara Ijon di Kecamatan Passi Barat.

Data Sekunder

Data sekunder adalah data yang diperoleh dari dokumen resmi, buku-buku, majalah dan berbagai literatur yang relevan dengan pembahasan penelitian ini. Jadi pengumpulan data sekunder ini melalui orang kedua baik berupa informan atau buku literatur yaitu buku-buku, artikel, surat kabar dan lain-lain yang berkaitan dengan pembahasan, (Soerjono Soekanto, 1986; 12) Data sekunder ini membantu peneliti untuk mendapatkan bukti maupun bahan yang akan diteliti, sehingga peneliti dapat memecahkan atau menyelesaikan suatu penelitian dengan baik karena didukung dari buku-buku, baik yang sudah dipublikasikan maupun yang belum dipublikasikan.

\section{Informan Penelitian}

Informan Penelitian mengenai Pemahaman Masyarakat tentang Jual Beli Gharar yaitu Praktek Jual Beli Ijon Buah Cengkeh yang masih di pohon Ini memerlukan informan yang mempunyai pemahaman yang berkaitan langsung dengan masalah penelitian guna memperoleh data dan informasi yang lebih akurat. Oleh sebab itu, informan yang dimaksud adalah Masyarakat Penjual dan Pembeli yang terlibat dalam praktek jual beli tersebut.

\section{Fokus Penelitian}

Penentuan fokus suatu penelitian memiliki dua tujuan. Pertama, penetapan fokus dapat membatasi studi, jadi dalam hal ini fokus akan membatasi bidang inquiry. Kedua, penetapan fokus ini berfungsi untuk memenuhi kriteria inklusi - eksklusi atau memasukkan - mengeluarkan suatu informasi yang diperoleh di lapangan (Soerjono Soekanto, 1986; 12)

\section{Teknik Pengumpulan Data}


e-ISSN; 2528-0325 ISSN; 2528-0317 Tasharruf : Vol. 2 No. 1 Juni 2017 Journal Economic and Business Of Islam

Sumber data dalam penelitian ini adalah kata-kata dan tindakan para informan sebagai data primer dan tulisan atau dokumen-dokumen yang mendukung pernyataan informan. Hal ini sebagaimana dinyatakan Lofland and Lofland dalam Moleong bahwa sumber data utama dalam penelitian kualitatif adalah kata-kata dan tindakan, selebihnya adalah data tambahan seperti dokumen dan lain-lain. Dalam penelitan ini, jenis data yang dikumpulkan adalah data primer dan data sekunder. Untuk mengumpulkan data primer dan sekunder peneliti menggunakan beberapa teknik pengumpulan data, yaitu:

\section{Observasi}

Metode observasi adalah dapat diartikan sebagai pengamatan dan pencatatan dengan sistematik fenomena-fenomena yang diselidiki, (Soerjono Soekanto, 1986; 112). Dengan demikian peneliti terjun langsung kelapangan atau kepada masyarakat dengan mengadakan pengamatan (melihat, mendengar, dan bertanya) dan pecatatan situasi masyarakat.

\section{Dokumentasi}

Metode dokumentasi adalah suatu upaya untuk mengumpulkan bukti-bukti atau data-data yang berkisar pada masalah demonografi daerah penelitian baik yang berbentuk tulisan pribadi seperti buku harian, surat-surat dan dokumen resmi yang bersumber dari arsip atau catatan (Soerjono Soekanto,1986; 161).

Dengan metode ini peneliti akan memperoleh data tentang gambaran umum obyek penelitian yang berhubungan dengan jumlah penduduk, peta Kecamatan Passi Barat dan sebagainya.

1. Wawancara

Metode wawancara adalah suatu cara pengumpulan data dengan cara komunikasi langsung antara peneliti dengan obyek peneliti (Lexy J. Moleong, 2001; 135). Metode ini digunakan untuk memperoleh data secara umum dari pedagang (penjual) yang memakai jual-beli dengan cara"borongan”. Sedangkan 
e-ISSN; 2528-0325 ISSN; 2528-0317 Tasharruf :

wawancara yang digunakan dalam penelitian ini adalah wawancara bebas terpimpin, yaitu kombinasi antara interview bebas dan interview terpimpin.

\section{Teknik Analisis Data}

Dalam rangka menjawab permasalahan penelitian, maka Analisis data dalam penelitian ini dilakukan secara kualitatif yaitu suatu analisis yang berusaha mencari pola, model, tema, hubungan, persamaan, dan makna dari data yang dinyatakan dalam bentuk pernyataan-pernyataan, tafsiran-tafsiran setelah menggali data dari beberapa orang informan kunci yang ditabulasikan dan dipresentasekan sesuai dengan hasil temuan (observasi) dan wawancara mendalam peneliti dengan para informan, hasil pengumpulan data tersebut diolah secara manual, direduksi selanjutnya hasil reduksi tersebut dikelompokkan dalam bentuk segmen tertentu (display data) dan kemudian disajikan dalam bentuk content analisis dengan penjelasan-penjelasan, selanjutnya diberi kesimpulan, sehingga dapat menjawab rumusan masalah, menjelaskan dan terfokus pada representasi tehadap fenomena yang hadir dalam penelitian.

Analisis data menurut Patton yang dikutip oleh Moleong adalah proses untuk mengatur urutan data, mengorganisasikannya kedalam suatu pola, kategori satuan dasar. Sedangkan menurut Bogdan dan Taylir analisis data adalah proses yang merinci usaha secara formal untuk menemukan tema dan merumuskan ide seperti yang disarankan oleh data dan sebagai usaha untuk memberikan bantuan pada tema dan ide itu (Koentjaraningrat, 1997; 270). Penafsiran lain yaitu proses penyederhanaan data ke dalam bentuk yang lebih mudah dibaca dan diinterpretasikan (Masri Singarimbun dan Sofian Effendi, 1984; 263.).

\section{HASIL PENELITIAN}

\section{Profil Kecamatan Passi Bara}

1. Gambaran Umum 


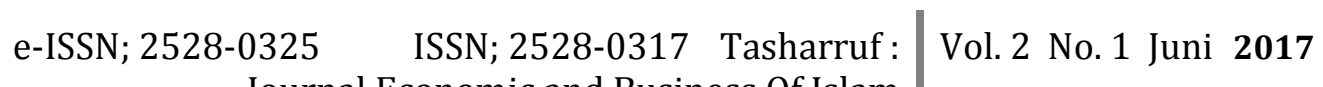
Journal Economic and Business Of Islam

Kecamatan Passi Barat merupakan wilayah pemekaran dari kecamatan Passi. dengan batas geografis sebagai berikut : Sebelah Utara : Kecamatan Bolaang, Sebelah Timur : Kecamatan Kotamobagu Barat, Sebelah Selatan : Kecamatan Bolaang, Sebelah Barat : Kecamatan Kotamobagu Utara dan Kecamatan Bilalang

Desa Passi yang menjadi Ibukota dari Kecamatan Passi Barat dapat diakses dari Ibu Kota Provinsi Sulawesi Utara (Kota Manado) dengan waktu tempuh + 4 Jam dan berjarak 236,72 Km. Sementara bila di akses dari Kota Kotamobagu hanya berjarak $12 \mathrm{Km}$ dengan waktu tempuh kurang dari 1 Jam.

Topografi Passi Barat beragam mulai dari dataran landai sampai bergelombang ringan dengan ketinggian tempat $450 \mathrm{~m}$ dpl (meter diatas permukaan laut) yang diukur dari ibu kota kecamatan. Kecamatan ini dilewati oleh sungai kecil maupun besar seperti sungai Katulidan, Sungai Muntoi dan Lobong.

Luas Kecamatan Passi Barat keseluruhannya mencapai 9.546 Hektar atau 2,72. persen dari Luas Kabupaten Bolaang Mongondow). Luas sawahnya hanya 174 hektar, sementara lahan yang digunakan untuk pemukiman 477 hektar (Hasil Sensus Potensi Desa, 2008). Di tahun 2010 Kecamatan Passi Barat memiliki 12 Desa, kesemuanya telah berstatus definitif.

Desa dengan luas terbesar adalah Desa Otam yaitu seluas 18,10 km2 atau 18,96 persen dari total luas Kecamatan sedangkan Desa yang memiliki luas terkecil adalah Desa Inuai yaitu hanya seluas 2,04 km2 atau sebesar 2,14 persen dari total luas wilayah Kecamatan.

\section{Penduduk}

Penduduk berdasarkan hasil sensus tahun 2010 sebanyak 14.951 jiwa yang terdiri dari penduduk laki-laki sebanyak 7.809 jiwa dan penduduk perempuan sebanyak 7.142 jiwa. Desa dengan Jumlah penduduk terbanyak adalah Desa Otam yaitu sebanyak 2.670 jiwa. Sex ratio keadaan tahun 2010 secara umun diatas seratus persen dan jika 


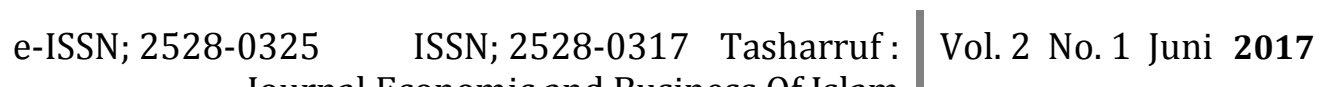
Journal Economic and Business Of Islam

dilhat sex ratio per Desa maka semua Desa juga diatas 100 persen, yang berarti penduduk laki-laki lebih banyak dari penduduk perempuan.

Tingkat kepadatan masih rendah, yaitu sebesar 156.62 penduduk per km2. Kepadatan penduduk disetiap Desa yang terpadat adalah Desa Muntoi yaitu sebanyak 419,49 penduduk per km2. Banyaknya Penduduk per rumahtangganya rata -rata 3,64.

\section{Tanaman Pangan}

Lual lahan pertanian di Kecamatan ini keadaan tahun 2010 untuk lahan sawah sebesar 175 hektar dan lahan pertanian bukan sawah sebesar 8.895,10 hektar.

Produksi Tanaman pangan di Kecamatan ini keadaan tahun 2010 adalah Padi Sawah sebanyak 736,25 ton dan jagung sebanyak sebanyak 625,5 ton.

\section{Industri dan Perdagangan}

Kegiatan sektor industri yang ada di Kecamatan Passi Barat keadaan sampai dengan tahun 2010 belum ada yang melakukan kegiatan secara ekonomi. Aktivitas pasar keadaan sampai dengan tahun 2010 belum ada di kecamatan Passi Barat. Sedangkan Warung keadaan tahun 2010 ada sebanyak 163 unit yang tersebar pada semua Desa yang ada. Desa dengan jumlah Warung terbanyak ada di Desa Muntoi yaitu sebanyak 27 unit usaha dan yang paling sedikit di Desa Poyuyanan hanya ada 7 unit Usaha.

\section{Transportasi dan Komunikasi}

Keberadaan transportasi dan komunikasi sangat penting untuk memperlancar akses dan mobilitas penduduk. Banyaknya alat transportasi darat di Kecamatan Passi Barat tahun 2010 yaitu kendaraan roda dua sebanyak 668 unit, kendaraan roda tiga sebanyak 197 unit dan kendaraan roda empat sebanyak 95 unit. Sedangkan sarana komunikasi yang ada di Kecamatan ini berupa telepon rumah sebanyak 9 unit, TV ada sebanayk 1.846 unit dan antenna parabola sebanyak 57 unit. 
e-ISSN; 2528-0325 ISSN; 2528-0317 Tasharruf : $\mid$ Vol. 2 No. 1 Juni 2017 Journal Economic and Business Of Islam

Tabel 4.2

Penduduk Menurut Jenis Kelamin dan Sex Ratio

Dirinci per Desa di Kecamatan Passi Barat Tahun 2010

\begin{tabular}{|r|l|c|c|c|}
\hline \multicolumn{1}{|c|}{ No } & \multicolumn{1}{|c|}{ Desa/Kelurahan } & Laki-Laki & Perempuan & Sex Ratio \\
\hline$(1)$ & \multicolumn{1}{|c|}{$(2)$} & $(3)$ & $(4)$ & $(5)$ \\
\hline 1. & Muntoi & 467 & 534 & 113,67 \\
\hline 2. & Inuai & 477 & 432 & 120,78 \\
\hline 3. & Poyuyanan & 938 & 909 & 110,42 \\
\hline 4. & Lobong & 867 & 774 & 103,19 \\
\hline 5. & Passi & 779 & 748 & 112,02 \\
\hline 6. & Wangga & 1.408 & 1.262 & 104,14 \\
\hline 7. & Otam & 487 & 457 & 111,57 \\
\hline 8. & Bulud & 579 & 556 & 106,56 \\
\hline 9. & Bintau & 869 & 778 & 111,70 \\
\hline 10. & Passi II & 333 & 307 & 108,47 \\
\hline 11. & Muntoi Timur & 7.809 & 7.142 & $\mathbf{1 5 6 , 6 2}$ \\
\hline & T O T A L & & \\
\hline
\end{tabular}

Sumber : Data Statistik Profil Kecamatan Se-Kab Bolaang Mongondow 2011, diakses Tanggal 1 November 2015

Tabel 4.4

Luas Lahan Pertanian

Dirinci Menurut Desa di Kecamatan Passi Barat Tahun 2010

\begin{tabular}{|c|c|c|c|}
\hline \multirow{2}{*}{ NO } & \multirow{2}{*}{ Desa/Kelurahan } & \multicolumn{2}{|c|}{ Pertanian } \\
\hline & & Sawah & Non Sawah \\
\hline 1. & Muntoi & 35,00 & 200,00 \\
\hline 2. & Inuai & 100,00 & 179,00 \\
\hline 3. & Poyuyanan & - & 845,00 \\
\hline 4. & Lobong & - & 768,00 \\
\hline
\end{tabular}


e-ISSN; 2528-0325 ISSN; 2528-0317 Tasharruf: Vol. 2 No. 1 Juni 2017 Journal Economic and Business Of Islam

\begin{tabular}{|c|c|c|c|}
\hline 5. & Passi & - & 632,00 \\
\hline 6. & Wangga & - & $1.103,00$ \\
\hline 7. & Otam & 40 & $401.723,00$ \\
\hline 8. & Bulud & - & $1.214,00$ \\
\hline 9. & Bintau & - & $1.362,00$ \\
\hline 10. & Passi II & - & 631,00 \\
\hline 11. & Muntoi Timur & - & 237,50 \\
\hline & TO T A L & 174,00 & $8.895,10$ \\
\hline
\end{tabular}

Sumber : Data Statistik Profil Kecamatan Se-Kab Bolaang Mongondow 2011, diakses Tanggal 1 November 2015

\section{A. Pelaksanaan Jual Beli Cengkeh yang Masih di Pohon (Ijon) dan Pemahaman} Masyarakat Terhadap Ijon di Kecamatan Passi Barat Cengkeh di Kecamatan Passi Barat.

Dari data yang diperoleh, maka pertama kali disini yang akan dianalisis adalah bagaimana proses pelaksanaan jual-beli buah Cengkeh yang masih dipohon yang dilakukan oleh masyarakat di Kecamatan Passi Barat Kabupaten Bolaang Mongondow.

Kebanyakan yang melakukan kegiatan jual beli ini adalah rata-rata masyarakat petani cengkeh yang berada dalam garis kehidupan menengah kebawah, artinya bahwa para petani yang menawarkan jual beli tersebut adalah mereka yang membutuhkan uang untuk keperluan sehari-hari. 
e-ISSN; 2528-0325 ISSN; 2528-0317 Tasharruf : Vol. 2 No. 1 Juni 2017 Journal Economic and Business Of Islam

Hal ini dapat dimengerti bahwa tanaman cengkeh adalah tanaman tahunan, sehingga untuk mencukupi kebutuhan sehari-hari tindakan yang harus kami lakukan salah satunya adalah dengan jalan menjual buah cengkeh sebelum masa panen yang dipergunakan untuk keperluan sehari-hari, misalnya membeli beras, gula, dan untuk keperluan anak pergi sekolah. ${ }^{1}$

Para pembeli yang ditawarkan oleh petani ini berfariasi, artinya ada yang langsung didatangi untuk ditawarkan oleh petani dan ada juga yang memanfaatkan kesempatan kepada para petani yang membutuhkan uang dengan cara membayar terlebih dahulu karena mendapatkan keuntungan yang berlipat ganda.

Biasanya harga yang ditawarkan berfariasi pula sesuai dengan akad perjanjian yang disepakati. Ada yang datang menawarkan $1 \mathrm{~kg}$. dijual dengan harga Rp. 30.000. dan apabila tiba masa panen bisaanya petani sendiri yang memanen dan menyerahkan kepada pembeli sesuai dengan jumlah yang dibayar sebelumnya. Bisaanya petani menjual buah cengkeh yang masih dipohon tersebut ada yang 20 kg. bahkan ada yang sampai $50 \mathrm{~kg}$. bahkan lebih. ${ }^{2}$

Jual beli seperti ini sangatlah menggiurkan, apabila dihitung keuntungan yang diperoleh sangat berlipat ganda. Jika dihitung dengan harga pasaran buah cengkeh kurang lebih Rp. 120.000 / kg. sehingga keuntungan yang didapatkan pada saat buah cengkeh dipanen berkisar Rp. 90.000/kilogramnya.

Adapun yang sengaja memanfaatkan kesempatan kepada petani yang membutuhkan tersebut, mereka langsung menawarkan harga dan sekaligus memanen buah cengkeh saat panen tiba. Harganyapun berfariasi dan bisaanya 1 Kg. buah cengkeh dibeli seharga Rp.18.500 sampai Rp. 20.000,-. Hal ini dikarenakan pada saat panen tiba, sang pembeli yang menyewa pemetik sekaligus ongkos pemetikannya ditanggung oleh pembeli. ${ }^{3}$ Dan banyaknya buah

\footnotetext{
${ }^{1}$ HB. Mamonto, Petani Cengkeh, Wawancara : Tanggal 2 November 2015

2 Taha Mamonto, Pembeli, Wawancara : Tanggal 8 November 2015.

${ }^{3}$ M. Mokoginta, Petani Cengkeh. Wawancara : Tanggal 8 November 2015.
} 
e-ISSN; 2528-0325 ISSN; 2528-0317 Tasharruf : Vol. 2 No. 1 Juni 2017 Journal Economic and Business Of Islam

cengkeh yang dipanen hanya sesuai dengan akad yang dibayarkan pada saat transaksi sebelumnya. ${ }^{4}$

Akad dalam jual-beli inipun berfariasi, artinya akad bisa dilakukan dirumah kedua belah pihak, atau akad bisa terjadi di kebun setelah pembeli melihat buah cengkeh, akan tetapi tidak semua buah cengkeh dapat dijual, hanya sesuai dengan taksiran pembeli buah cengkeh yang dilihat.

Jual beli buah cengkeh yang masih di Pohon oleh sebagian masyarakat sudah menjadi kebisaaan dengan alasan ekonomi. Berdasarkan hasil observasi peneliti, jual beli buah cengkeh yang masih di pohon yang dilakukan oleh petani cengkeh di Kecamatan Passi Barat secara umum terbagi menjadi:

1. Menjual buah cengkeh di Pohon yang belum Nampak atau jelas buahnya

Model jual beli seperti ini, banyak dijumpai dalam masyarakat. Alasan yang dikemukakan pula hanya persoalan ekonomi demi mencukupi kebutuhan seharihari, bahkan lebih fatal lagi, mereka para petani cengkeh menjual buahnya yang belum kelihatan atau belum berbuah (spekulasi). Alasan yang dikemukan adalah taksiran jumlah dan bobot buah cengkeh sesuai dengan pengalaman panen sebelumnya.

Biasanya dalam pelaksanaan transaksi seperti ini adalah saling kepercayaan dengan menjual dan mengambil uang kepada pembeli yang memang sudah mengetahui persis buah cengkeh yang ada di kebun. ${ }^{5}$ Akan tetapi, sering pula pembeli tidak mengambil atau membeli dengan jumlah yang banyak, dengan pertimbangan waktu yang cukup panjang karena pohon cengkeh belum berbuah dan menjaga jangan sampai tidak berbuah. ${ }^{6}$

Harga yang diberikan pula sangat variatif berdasarkan permintaan dan penawaran yang dilakukan. Jika buah cengkeh nantinya berbuah, dan buahnya dipanen oleh si

\footnotetext{
${ }^{4}$ H. Kandoli, Petani Cengkeh, Wawancara : Tanggal 9 November 2015.

5 Dj. Pobela, Petani Cengkeh, Wawancara : 10 November 2015.

${ }^{6}$ I. Mamonto, Pembeli, Wawancara : 10 November 2015.
} 
e-ISSN; 2528-0325 ISSN; 2528-0317 Tasharruf : Vol. 2 No. 1 Juni 2017 Journal Economic and Business Of Islam

pembeli, maka harga yang ditawarkan pula sedikit murah, dan apabila si pembeli tidak memanen, menunggu hasil panen dari si pemilik, maka harganyapun sedikit mahal. $^{7}$

Pada kenyataannya bahwa, mereka yang membeli dan memanen sendiri buah cengkeh tersebut adalah para petani yang memang mempunyai pohon cengkeh dan mampu memanen sendiri. Sedangkan bagi para pembeli yang tidak sanggup memanen sendiri, bisaanya mereka yang punya profesi bukan petani dan mempercayakan kepada petani itu sendiri untuk memanen dan memberikan hasil panen tersebut sesuai dengan jumlah yang disepakati, dan bisaanya para petani tersebut tidak pernah lalai atau ketika pohon cengkeh berbuah dan sudah tiba saatnya panen, mereka mengantarkan sendiri ke rumah pembeli. ${ }^{8}$

Dalam proses jual beli seperti ini, ada kerugian tersendiri yang dialami oleh para petani, sebab harga yang dibayarkan sebelumnya sangat berbeda jauh dengan harga jual di pasaran pada umumnya. Bisa dibayangkan keuntungan yang diperoleh dari proses jual beli ini, kisarannya lebih dari 3 kali lipat keuntungan dari harga beli.

2. Menjual buah cengkeh yang masih di pohon tetapi sudah nampak dan jelas buahnya

Proses jual beli ini, tidak berbeda jauh dengan proses transaksi jual beli sebagaimana dijelaskan diatas. Hanya saja yang membedakannya adalah dari segi buahnya yang sudah nampak.

Dalam proses menawarkan kepada pembeli, kami tidak mendapatkan kesulitan, karena buah cengkeh yang ditawarkan sudah ada dan Nampak di pohon, sehingga pembelipun tidak ragu untuk membayarnya. ${ }^{9}$

\footnotetext{
${ }^{7}$ B. Adampe. Petani Cengkeh, Wawancara : 11 November 2015.

${ }^{8}$ Hamzah M. Tokoh Masyarakat, Wawancara : 12 November 2015.

${ }^{9}$ Hamsalim Mokobombang, Petani Cengkeh, Wawancara : 12 November 2015.
} 
e-ISSN; 2528-0325 ISSN; 2528-0317 Tasharruf : Vol. 2 No. 1 Juni 2017 Journal Economic and Business Of Islam

Bisaanya para petani dalam melakukan transaksi ini sudah tidak ragu lagi untuk menawarkan kepada pembeli karena buah cengkeh sudah nampak jelas berbuah, tinggal menunggu masa panennya, dan para pembeli yang ditawarkan pula sudah tidak ragu untuk membayar sesuai dengan harga yang ditawarkan oleh petani.

Hanya saja, dalam persoalan akad penjualan, terjadi perbedaan harga dan penawaran dari si pembeli. Seandainya disepakati dalam akad bahwa si petani cengkeh yang memanen pada saat tiba masa panen, maka bisaanya harganya agak sedikit tinggi. Namun apabila si pembeli yang memanen sendiri buahnya pada saat panen maka harganya sedikit direndah. ${ }^{10}$

Hal tersebut merupakan suatu kewajaran, karena pertimbangan biaya pemetikan. Berdasarkan hasil observasi peneliti, pada umumnya perkebunan cengkeh masyarakat di Kecamatan Passi Barat berada jauh dari perkampungan dengan perjalanan yang cukup melelahkan karena harus ditempuh dengan jalan kaki. Disamping itu pula untuk memanen buah cengkeh harus menyewa orang yang memetik.

3. Menjual buah cengkeh yang masih di pohon dengan cara menjual keseluruhan sesuai dengan akad perjanjian dengan masa panen 2 sampai dengan 3 kali atau lebih.

Jual beli model seperti ini, memang tidak banyak dijumpai dalam masyarakat. Berdasarkan hasil observasi peneliti, bisaanya petani yang menjual buah cengkeh ini, mempunyai profesi lain, misalnya penambang, sopir dan pedagang.

Dalam prakteknya bahwa jual beli seperti ini adalah menjual secara borongan keseluruhan buahnya selama beberapa kali panen sesuai dengan kesepakatan antara si pemilik cengkeh dan pembeli. Nanti selesai masa pembelian sesuai dengan kesepakatan tersebut, maka si pemilik berhak mengambil kembali.

10 Adam Mamonto, Petani Cengkeh, Wawancara : 12 November 2015 
e-ISSN; 2528-0325 ISSN; 2528-0317 Tasharruf : Vol. 2 No. 1 Juni 2017 Journal Economic and Business Of Islam

Dari ketiga bentuk jual beli sebagaimana tersebut diatas, pemahaman masyarakat khususnya para petani cengkeh tentang jual beli Ijon ini sangat beragam, bahkan ada yang sama sekali tidak memahaminya.

Keberagaman tersebut sesuai hasil observasi dan pengamatan peneliti karena dipengaruhi oleh Minimya Pengetahuan Agama.

Secara umum yang menyebabkan minimnya pemahaman masyarakat terhadap persoalan jual beli ijon ini disebabkan oleh minimnya pengetahuan agama. Informasi tentang persoalan Ijon sesuai dengan hasil observasi tanya jawab peneliti rata-rata tidak mengetahui bahkan tidak bisa menjawab.

Dari keseluruhan Informan diatas sebagai pemberi informasi dan mereka para pelaku kurang memahami tentang persoalan hukum agama mengenai ijon.

Secara hati nurani, bahwa jual beli model seperti ini sangatlah merugikan, tapi karena persoalan kebutuhan, terpaksa dilakukan, bahkan jika dipikir-pikir, kami sangat rugi, tetapi karena tidak ada jalan lain, sementara kebutuhan pula mendesak, terpaksa hanya dengan jalan ini yang bisa dilakukan. $^{11}$

Dalam kegiatan - kegiatan keagamaan yang dilaksanakan oleh masyarakat, baik dalam memperingati hari-hari besar Islam maupun pada khutbah Jum'at dan kegiatan-kegiatan lain, persoalan ini tidak pernah diangkat bahkan dibahas dalam ceramah dan sebagainya. ${ }^{12}$

Pada hakekatnya, masyarakat memahami betul bahwa transaksi jual beli ijon seperti ini, dilarang oleh agama dan apa yang mereka lakukan adalah salah terutama dalam persoalan keuntungan yang berlipat ganda, bukan pada persoalan dibolehkan atau tidaknya jual beli ijon ini.

\footnotetext{
${ }^{11}$ Ismail Sugeha, Petani Cengkeh, Wawancara : 13 November 2015.

${ }^{12}$ A. Ponengoh, Tokoh Agama, Wawancara : 14 November 2015.
} 
e-ISSN; 2528-0325 ISSN; 2528-0317 Tasharruf : Vol. 2 No. 1 Juni 2017 Journal Economic and Business Of Islam

Disamping persoalan minimnya pengetahuan agama, faktor pendidikan pula sangat menentukan. Berdasarkan hasil observasi, bahwa rata-rata tingkat pendidikan informan adalah lulusan Sekolah Dasar dan putus Sekolah. Pada umumnya mereka lebih memilih berkebun dari pada sekolah, karena pemahaman masyarakat dulunya, mereka beranggapan bahwa sekolah tidak menghasilkan apa-apa dan tidak memberikan mereka makan. Bersekolah hanya akan menambah beban biaya yang harus ditanggung. Mereka lebih senang jika anak mereka pergi bekerja untuk memenuhi kebutuhan keluarga.

Faktor ijon ini, menurut pengamatan peneliti secara umum di kecamatan Passi Barat adalah faktor penyebab kemiskinan. Petani terpaksa harus mengambil ijon untuk menyambung hidupnya meskipun itu sangat merugikan. Betapa tidak, karena ijon adalah sebuah sistem pemberian atau membantu dengan pinjaman uang kepada para petani dengan perjanjian bahwa uang dikembalikan dalam bentuk hasil panen buah cengkeh yang harganya jauh

\section{PENUTUP}

\section{KESIMPULAN}

Dari hasil penelitian yang dilakukan terhadap Pemahaman Masyarakat tentang Jual Beli Cengkeh yang masih di Pohon (Ijon) di Kecamatan Passi Barat Kabupaten Bolaang Mongondow dapat disimpulkan bahwa :

1. Proses pelaksanaan Masyarakat yang melakukan kegiatan jual beli ini adalah rata-rata masyarakat petani cengkeh yang berada dalam garis kehidupan menengah kebawah, artinya bahwa para petani yang menawarkan jual beli tersebut adalah mereka yang membutuhkan uang untuk keperluan sehari-hari.

2. Pada Pelaksanaan Jual Beli ini, Biasanya harga yang ditawarkan berfariasi sesuai dengan akad perjanjian yang disepakati. Ada yang datang menawarkan $1 \mathrm{~kg}$. dijual dengan harga Rp. 30.000. dan apabila tiba masa panen bisaanya petani sendiri yang memanen dan menyerahkan kepada pembeli sesuai dengan 
e-ISSN; 2528-0325 ISSN; 2528-0317 Tasharruf : Vol. 2 No. 1 Juni 2017 Journal Economic and Business Of Islam

jumlah yang dibayar sebelumnya. Bisaanya petani menjual buah cengkeh yang masih dipohon tersebut ada yang $20 \mathrm{~kg}$. bahkan ada yang sampai $50 \mathrm{~kg}$. bahkan lebih.

3. Adapun yang sengaja memanfaatkan kesempatan kepada petani yang membutuhkan tersebut, mereka langsung menawarkan harga dan sekaligus memanen buah cengkeh saat panen tiba. Harganyapun berfariasi dan bisaanya $1 \mathrm{Kg}$. buah cengkeh dibelise harga Rp.18.500 sampai Rp. 20.000,-. Hal ini dikarenakan pada saat panen tiba, sang pembeli yang menyewa pemetik sekaligus ongkos pemetikannya ditanggung oleh pembeli. Dan banyaknya buah cengkeh yang dipanen hanya sesuai dengan akad yang dibayarkan pada saat transaksi sebelumnya

4. Pemahaman masyarakatk hususnya para petani cengkeh tentang jual beli Ijon ini sangat beragam, bahkan ada yang sama sekali tidak memahaminya. Keberagaman tersebut sesuai hasil observasi dan pengamatan peneliti karena dipengaruhi oleh Minimya Pengetahuan Agama. Informasi tentang persoalan Ijon sesuai dengan hasil observasi tanyajawab peneliti rata-rata tidak mengetahui bahkan tidak bisa menjawab.

\section{A. SARAN}

Berdasarkan penelitian yang telah dilakukan ini terdapat beberapa saran untuk sebagai berikut:

1. Kepada para petani alangkah baiknya hasil produksi pertanian yang berupa cengkeh tidak dijual secara Ijon, karena akan berdampak terhadap kerugian pendapatan penghasilan petani.

2. Pemerintah setempat setidaknya member kontribusi untuk memecahkan permasalahan ini dengan mendirikan wadah berupa Koperasi Simpan Pinjam bagi para petani serta menggalakkan kegiatan keagamaan minimal mendapatkan informasi dan konstribusi terhadap pengetahuan masyarakat menyangkut Hukum dan Dampak dari pada Jual Beli secara Ijon.

\section{K E P U S T A K A A N}

Abdul Sami' al-Misri, 2006, Pilar-Pilar Ekonomi Islam, Cet. I; Pustaka Pelajar 


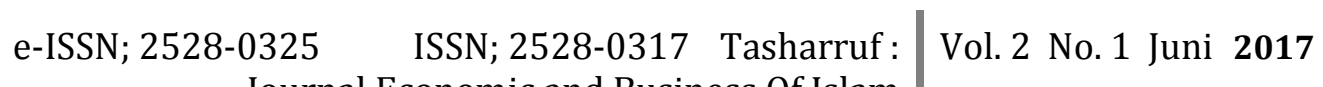
Journal Economic and Business Of Islam

Ahmad Azhar Basyir, 2000, Asasa-Asas Hukum Muamalah, Yogyakarta: UII Press

Ahmad Muhammad al-Assal, dkk.,1999, Sistem Prinsip dan Tujuan Ekonomi Islam, alih bahasa: H.Imam Saefuddin, Cet. I; Bandung : Pustaka Setia

Anas Sudiyono, 1996 Pengantar Evaluasi Pendidikan, Jakarta: Raja Grafindo Persada

As-Sayyid-Sabiq, 1998 Fiqh Sunnah, alih bahasa Kamaludin A. Marzuki, Bandung: Ma'arif

Data Statistik Kabupaten Bolaang Mongondow Tahun 2010, Diakses pada Tanggal 1 November 2015.

Djuretnaa Imam Muhni, 1994 Moral dan Religi menurut Emile Durkheim dan Hendri Bergson, Yokyakarta: Kanisius

Ghufron A. Mas'adi, 2002, Fiqh Muamalah Kontekstual, Jakarta: Rajawali Pers

Hamzah Ya'qub, 1992, Kode Etik Dagang Menurut Islam: Pola Pembinaan Dalam Hidup Berekonomi, Bandung: CV. Diponegoro

Ibnu Rusyd, 1990, Terjemah Bidayatul Mujtahid, Semarang: CV. As-Sifa

Koentjaraningrat, 1997, Metode Penelitian Masyarakat, Jakarta: P.T. Gramedia Pustaka Utama

Lexi,. J. Moleong, 2001, Metodologi Penelitian Kualitatif, Bandung: PT. Remaja Rosdakarya

M. Ali Hasan, 2003, Berbagai Macam Transaksi dalam Islam, Cet. I; Jakarta: Rajawali Pers

Marzuki, 1986, Metode Riset, Yogyakarta: BPFE UII

Masri Singarimbun dan Sofian Effendi, 1984, Metode Penelitian Survei, Jakarta: Ghalia Indonesia

Muhammad Ali, 1996, Guru Dalam Proses Belajar Mengajar, Bandung: Sinar baru Algensindo 


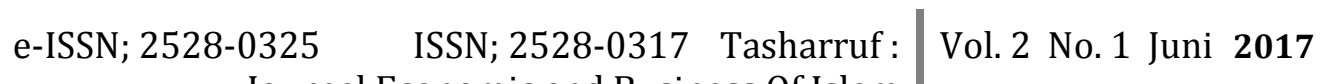
Journal Economic and Business Of Islam

Nana Sudjana, Penilaian Hasil Proses Balajar Mengajar, Bandung: PT. Remaja Rosdakarya, 2008

Ngalim Purwanto, 1997, Prinsip- Prinsip Dan Teknik Evaluasi Pengajaran, Bandung: PT. Remaja Rosdakarya

Paul A Partanto dan M. Dahlan Al Barry, 2001, Kamus Ilmiah Popular, Surabaya: Arloka

Plus A.Partanto M. Dahlan AL-Bary, 1994, Kamus Ilmiah Populer, Surabaya: Arkolo

Rahmat Syafe'i, 2006, Fiqh Muamalah, Cet. III; Bandung: Pustaka Setia

Setrisno Hadi, 1986, Metode Risech II, Yogyakarta: Yayasan Penerbit Psikologi UGM

Soerjono Soekanto, 2006, Penelitian Hukum Normatif, Jakarta: Raja Grafindo Persada

Soerjono Soekanto, 1986, Pengantar Penelitian Hukum, Jakarta: Rineka Cipta

Soleman B. Taneko, 1984, Struktur dan Proses Sosial: Suatu Pengantar Sosiologi Pembangunan, Jakarta: Rajawali

Suharsimi Arikunto, 2002, Prosedur Penelitian Suatu Pendekatan Praktis, Jakarta: Bina Aksara

W.J.S. Porwadarminto, 1991, Kamus Besar Bahasa Indonesia, Jakarta: Balai Pustaka

Yusuf Anas, 2009, Managemen Pembelajaran dan Instruksi Pendidikan, Jogjakarta: IRCiSoD 


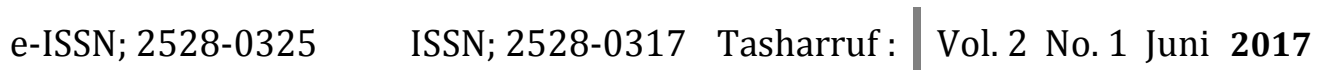
Journal Economic and Business Of Islam 